Shadows of Doubt 



\title{
Shadows of Doubt
}

Stereotypes, Crime, and the Pursuit of Justice

\author{
Brendan O'Flaherty \\ Rajiv Sethi
}

II Harvard University Press

Cambridge, Massachusetts

London, England

2019 
Copyright (C) 2019 by the President and Fellows of Harvard College All rights reserved

Printed in the United States of America

First printing

Design by Dean Bornstein

Jacket photograph: Alex Linch / Shutterstock

Jacket design: Chrissy Kurpeski

9780674240179 (EPUB)

9780674240186 (MOBI)

$9780674240162(\mathrm{PDF})$

The Library of Congress has cataloged the printed edition as follows:

Names: O’Flaherty, Brendan, author. | Sethi, Rajiv, I963-author.

Title: Shadows of doubt : stereotypes, crime, and the pursuit of justice / Brendan O'Flaherty, Rajiv Sethi.

Description: Cambridge, Massachusetts : Harvard University Press, 20I9. | Includes bibliographical references and index.

Identifiers: LCCN 2018047862 | ISBN 9780674976597 (alk. paper)

Subjects: LCSH: Discrimination in criminal justice administration-United States. | Stereotypes (Social psychology)—United States. |

Discrimination-United States. | Discrimination in law enforcementUnited States.

Classification: LCC HV9950.O25 2019 | DDC 364.97308—dc23

LC record available at https://1ccn.loc.gov/2018047862 
In memory of Marjorie Miller and Patrick J. Gallagher 
